\title{
TOMATO YELLOW LEAF CURL VIRUS (TYLCV) STRAINS AND EPIDEMIOLOGICAL ROLE OF BEMISIA TABACI (HEMIPTERA: ALEYRODIDAE) BIOTYPES ON TOMATO AGROECOLOGY IN TURKEY
}

\author{
FIDAN, H. ${ }^{1 *}-$ KARACAOGLU, M. ${ }^{2}-$ KOC, G. $^{3}-$ CAGLAR, B. K. ${ }^{4}$ \\ ${ }^{1}$ Plant Protection Department, Faculty of Agriculture, Akdeniz University, Antalya, Turkey \\ ${ }^{2}$ Plant Protection Department, Faculty of Agriculture, Malatya Turgut Ozal University, \\ Malatya, Turkey \\ ${ }^{3}$ Subtropical Fruits Research and Experimental Center, Çukurova University, Adana, Turkey \\ ${ }^{4}$ Department of Plant Protection, Faculty of Agriculture, Cukurova University, Adana, Turkey \\ *Corresponding author \\ e-mail: hakanfidantr@hotmail.com.tr
}

(Received $18^{\text {th }}$ Mar 2019; accepted $3^{\text {rd }}$ May 2019)

\begin{abstract}
The aim of this study was to determine the strains of tomato yellow leaf curl virus (TYLCV) on the tomato plants growing intensively in Adana, Mersin and Antalya provinces and also investigate the transmissibility of virus by the vector B. tabaci biotypes in 2015 and 2017. For this purpose, unperiodical field observations were paid in different districts of those provinces. The TYLCV infected tomato plants and whiteflies on these plants were collected from different greenhouses and fields. The 747 samples of tomato infected with TYLCV were tested by PCR techniques. It was determined that the strains TYLCVIsrael, TYLCV-Sicilia, TYLCV-Sardinia and TYLCV-Mild were found to be infected via strain specific primers. PCR study also indicated that the same strains of TYLCV were also found on the whitefly samples collected from the infected tomato plants. DNA analyses by using specific primer Bem 23-F and $\mathrm{R}$ in an individual single whitefly, due to clarification of $B$. tabaci biotypes, has clearly showed that biotype B is a common vector of TYLCV in Turkey. Molecular techniques identified that Israel, Sardinia, Sicilia and Mild strain of TYLCV were present in three tomato cultivation areas in Mediterranean Region. B. tabaci biotype $B$ (formerly $B$. argentifolii) was detected as a vector of those of strains. It was observed that (\%92) B. tabaci Biotype B and (\%8) Biotype Q others were responsible for transmission as vector of TYLC respectively. Individual viruliferous Biotype B samples examined in PCR showed that the most determined TYLCV strain as Israel was the most common among the strains, what were identified.
\end{abstract}

Keywords: TYLCV strains' molecular epidemiology, Bemisia tabaci biotypes, impact on agroecology, Turkey

\section{Introduction}

Tomato yellow leaf curl virus (TYLCV) is a member of Begomovirus genus in Geminiviridae family causes severe crop losses in tomato cultivars up to $100 \%$ (Czosnek and Laterrot, 1997). It has a broad host range with various plant families such as Solanaceae (tomato, peppers, various nightshade weeds, and ornamental plants), Malvaceae (cheeseweed) and Fabaceae (beans). TYLCV causes yellow leaf edges, upward leaf curling, leaf mottling, small leaf, and flower drop. The infected plants in early stages do not bear fruit and stunting, depend on seasonal conditions and cvs. susceptibility, is observed on plants. TYLCV genome consists of circular, singlestranded DNA (ssDNA) approximately $2.7 \mathrm{~kb}$ long (Gronenborn, 2007). Long-distance 
spread of TYLCV occurs primarily by movement of infected plant material or by wind dispersal of whiteflies, acquisited the virus (Torre et al., 2018). The virus, was first discovered in 1939 in Israel and Jordan (Avidov, 1944), was officially named Tomato yellow leaf curl virus (TYLCV) and consists of different strains; Tomato yellow leaf curl Israel (TYLCSV-Is), Tomato yellow leaf curl virus-Mild (TYLCV-Mld), Sardinia (TYLCV-Sa), Tomato yellow leaf curl Sicily (TYLCSV-Sic), Tomato yellow leaf curl virus-Morocco (TYLCV-Mo), Tomato yellow leaf curl Malaga (TYLCV-Mal) Tomato yellow leaf curl Axarquia (TYLCV-Ax), Tomato yellow leaf curl China (TYLCV-Ch) and Tomato yellow leaf curl Thailand (TYLCV-Th.) (Fauquet et al., 2008; Abhary et al., 2006).

Since, the disease has spread rapidly to the Middle East and the Mediterranean coast, Asia, Africa, Europe, the United States, Australia, Italy and many other countries (Accotto et al., 2000; Boulton, 2003; Moriones and Navas-Castillo, 2000). In Turkey, TYLCV was first discovered in Mediterranean region by Yilmaz (1978). And then it was reported as the most devastating virus disease at tomato both in greenhouses and the field in Turkey by Abak et al. (1991). On the other hand, presence of whiteflies was known well in Cukurova region due to its severe damage to cotton production (Karut et al., 2015; Satar and Ulusoy, 2016)

Whiteflies are insects belonging to family Aleyrodidae which cause direct by phloem-feeding and indirect damage by transmission of viruses including begomoviruses (Brown and Czosnek, 2002; Jones, 2003; Navas-Castillo et al., 2011). The transmission of TYLCV by whiteflies is circulative semi-persistent manner. There are several reports of whitefly presence and economic damage in Turkey (Ulusoy et al., 2012; Bayhan et al., 2006). Morphological discrimination of whitefly biotypes is difficult. But it is possible by using molecular methods (Papayiannis et al., 2009). Most common whitefly biotypes in Turkey are biotype B and Q (Karut et al., 2012; Satar and Ulusoy, 2016) similar with various reports around the world (Konjevic et al., 2018; Li et al., 2017)

The aim of this work was to investigate of TYLCV strains epidemiology and its strict vector Bemisia tabaci biotypes on agroecology by reliable technique such as Polymerase Chain Reaction (PCR) in southern coast of Turkey. In fact, that there is not any verification.

\section{Materials and methods}

Surveys were conducted in Adana and Mersin provinces having typical Mediterranean climate in Turkey. Leaf samples from symptomatic tomato plants that showing typical TYLCV symptoms (upward leaf curling, yellowing, distortion and stunting) asymptomatic leaf samples as negative control and whiteflies were collected from 245 different greenhouses which were located in several areas in south of Turkey (Adana, Mersin, Antalya) (Fig. 1).

\section{Total RNA isolation, polymerase chain reaction $(P C R)$ and phylogenetic analysis}

Total DNA was extracted from leaf tissues according to Scientific GeneJET Plant Genomic DNA Purification Mini Kit. Strain-specific primers identified by Anfoka et al. (2005, 2008) were used to determine TYLCV strains (Tables 1 and 2).

DNA extraction from an individual whitefly: Total DNA was isolated from individual whiteflies as described by Zeidan and Czosnek (1991). In the modified 
simple procedure, individual whiteflies were ground $40 \mu 1$ of DNA extraction buffer (50 mM Thris. $\mathrm{HCl}$ (pH8.0), 0.5\% Tween 20, $0.025 \mathrm{mg} / \mathrm{ml}$ Proteinase K) and incubated at $65{ }^{\circ} \mathrm{C}$ for $2 \mathrm{~h}$. After incubation, $20 \mu \mathrm{l} 5 \mathrm{M}$ potassium acetate was added and placed on ice $5-15 \mathrm{~min}$. Centrifuged $10 \mathrm{~min}$ and placed $50 \mu \mathrm{l}$ of supernatant into a $1.5 \mathrm{ml}$ micro centrifuge tube. Added $30 \mu \mathrm{l}$ cold isopropanol, mix, and hold on ice about $5 \mathrm{~min}$ centrifuged $10 \mathrm{~min}$, draw off and discarded most of the supernatant, added $75 \mu 1$ of cold $70 \%$ ethanol, mix gently, and centrifuge $2 \mathrm{~min}$, Remove and discard nearly all of the supernatant being careful to not remove the pellets. Let pellets dry for about $10 \mathrm{~min}$ then add $40 \mu \mathrm{l}$ of sterile distilled water. These DNAs were used to identify white fly biotypes with the codominant SCAR markers Bem-23 (Bel-Kadhi, 2008) (Table 1). The PCR of TYLCV strains were obtained with DreamTaq Green PCR Master Mix (2X) (K1081Thermo Scientific, Germany) according to the manufacturer's instructions. PCR cycle parameters were as follows: one cycle at $95^{\circ} \mathrm{C}$ for $3 \mathrm{~min} ; 36$ cycles at $95{ }^{\circ} \mathrm{C}$ for $45 \mathrm{~s}$, I, Primer Set 52, II. Primer set $62^{\circ}$ and Whitefly primer $55^{\circ} \mathrm{C}$ for $45 \mathrm{~s}$, and $72{ }^{\circ} \mathrm{C}$ for $45 \mathrm{~s}$, followed by one cycle at $72{ }^{\circ} \mathrm{C}$ for $7 \mathrm{~min}$ and lastly storing at $4{ }^{\circ} \mathrm{C}$ until electrophoresis.

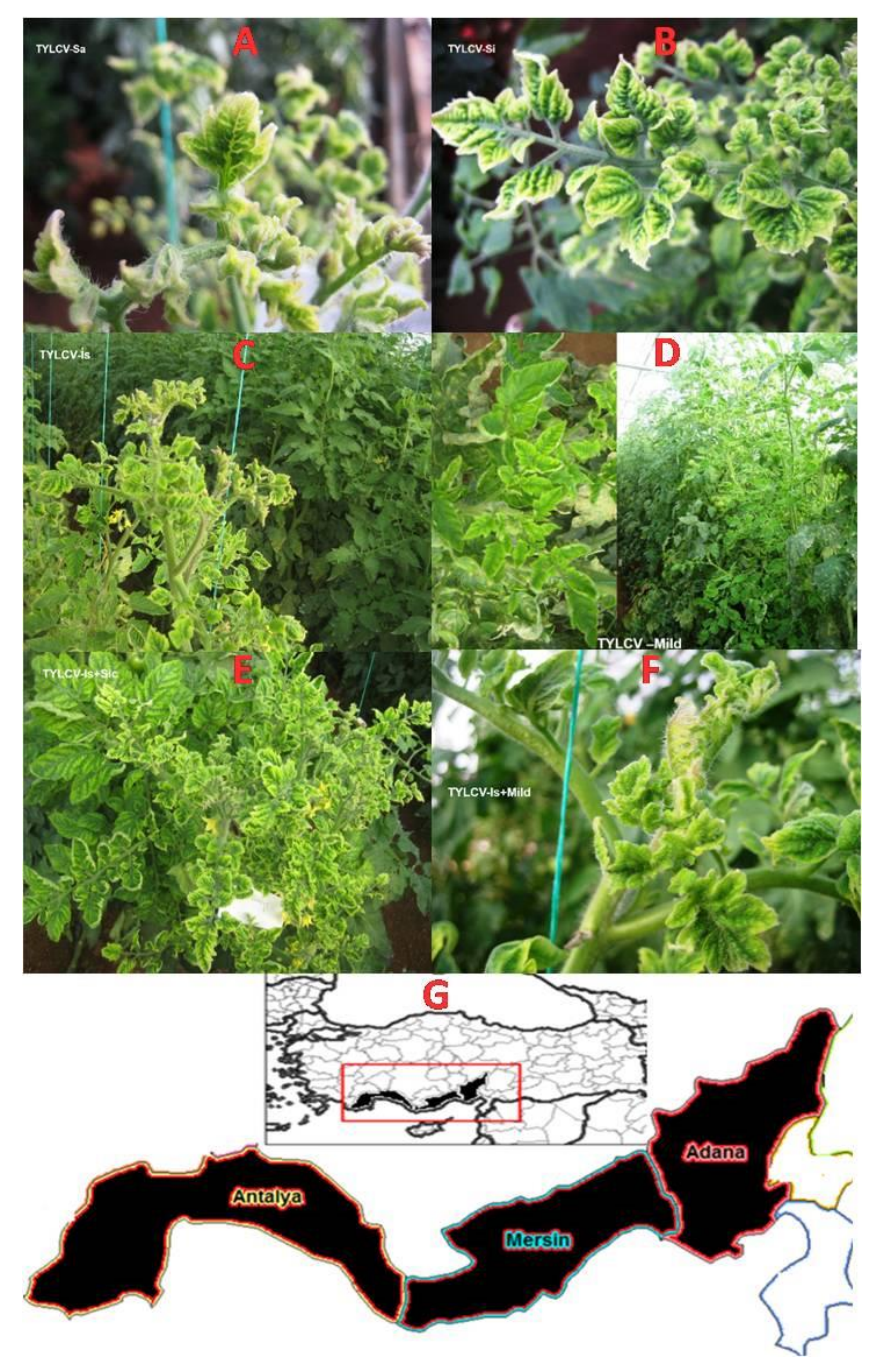

Figure 1. TYLVC symptoms of different strains from Turkey. A: TYLCV-Sar.; B: TYLCV-Sic; C: TYLCV-Is; D: TYLCV-Mil.; E: TYLCV-Is + Sic.; F: TYLCV-Is + Mild; G: Surveying map of Mediterranean area of Turkey 
Table 1. Strain -specific primer codes and sequences (5'-3') used in identification of TYLCV strains

\begin{tabular}{c|c}
\hline Primer codes for TYLCV & Sequences \\
\hline TYLCV1 & 5'-TTTTATTTGTTGGTGTTTGTAGTTGAAG-3' \\
TYLCV2 & 5'-ATATTGATGGTTTTTTCAAAACTTAGAAG-3' \\
TYLCV3 & 5'-ACGTAGGTCTTGACATCTGTTGAGCTC-3' \\
TYLCV4 & 5'-AAGTGGGTCCCACATATTGCAAGAC-3' \\
TYLCV5 & 5'-ATTGACCAAGATTTTTACACTTATCCC-3' \\
TYLCV6 & 5'-ATACTTGGACACCTAATGGCTATTTGG-3' \\
TYLCV7 & 5'-TGCCTTGGACA(A/G)TGGGG(A/G)CAGCAG-3' \\
TYLCV8 & 5'-TGGAAAGTACCCCATTCAAGAACATC-3' \\
\hline Primer codes for B. tabaci biotypes & Sequences \\
\hline Bem-23-F & 5'-CGGAGCTTGCGCCTTAGTC-3' B Biotype 220 bp \\
Bem-23-R & 5'-CGGCTTTATCATAGCTCTCGT-3' Q Biotype 410 bp \\
\hline
\end{tabular}

Table 2. Strain-specific primer pairs for PCR and the expected PCR product sizes

\begin{tabular}{c|c|c}
\hline $\begin{array}{c}\text { Strain-specific primer pairs for different TYLCV } \\
\text { strains }\end{array}$ & Primer codes & Expected product size \\
\hline $\begin{array}{c}\text { Multiplex PCR: I primer combination } \\
\text { Tomato yellow leaf curl virus (TYLCV-Is) }\end{array}$ & TYLCV6, TYLCV7 & $543 \mathrm{bp}$ \\
Tomato yellow leaf curl virus-Sicilia (TYLCV-Sic) & TYLCV8, TYLCV6 & $946 \mathrm{bp}$ \\
Tomato yellow leaf curl virus-Mild (TYLCV-Mld) & TYLCV5, TYLCV4 & $316 \mathrm{bp}$ \\
\hline Multiplex PCR II. primer combination & & \\
Tomato yellow leaf curl virus-Israel (TYLCV-Is) & TYLCV3, TYLCV4 & $634 \mathrm{bp}$ \\
Tomato yellow leaf curl virus Sardinia (TYLCSV-Sa) & TYLCV1, TYLCV2 & $433 \mathrm{bp}$ \\
Tomato yellow leaf curl virus-Mild (TYLCV-Mld) & TYLCV5, TYLCV4 & $316 \mathrm{bp}$ \\
\hline
\end{tabular}

\section{Analysis of PCR products}

PCR reaction mixture (Ten microlitres) was combined with gel loading buffer and analyzed on a $1.5 \%$ agarose gel containing $0.5 \mathrm{mg} / \mathrm{ml}$ of ethidium bromide and photographed (Sambrook et al., 1989). 100 bp DNA ladder (Thermo) or Bio Marker ${ }^{\mathrm{TM}}$ Low (Bio Ventures, Inc.) were used on each gel to determine the length of the amplified product. PCR-amplicons run at $100 \mathrm{~V}$ for 70 to $80 \mathrm{~min}$, and the gel was stained with ethidium bromide.

\section{Sequence analysis}

Expected PCR products from TYLCV strains were re-amplified by using Finnzymes' Phusion ${ }^{\circledR}$ High-Fidelity DNA Polymerase enzyme and $10 \mu \mathrm{l}$ of PCR products were checked. Remaining PCR products were sent to Sentobiolab commercial firm and nucleotide sequence of amplified regions were determined. Nucleotide sequences were checked and edited by using Bioedit then checked for protein synthesis to determine the sequences are significant or not by ExPASy programme. Valid sequences were compared with strains of TYLCV gen bank (NCBI, National Center for Biotechnology Information). 


\section{Results}

Surveys are conducted for collecting whiteflies and young tomato leaf samples from symptomatic plants that are related with suspicion of TYLCV infection from Adana, Antalya and Mersin between 2015 and 2017 (Table 3). Virus symptoms differ due to various factors such as climate, plant variety and infection period. It is common using indicator plants to identify the viral agent meanwhile for TYLCV, there is no practical identification method than molecular characterization of strains due to not transmitted by mechanic transmission. On the other hand, no symptomatic differences between TYLCV strains were observed up to date.

Table 3. Collected virus isolate numbers and locations according to province and districts

\begin{tabular}{l|c|c|c|c|c|c|c|c|c|c|c|c}
\hline & Province & \multicolumn{2}{|c|}{ Samples } & Province & \multicolumn{3}{|c|}{ Samples } & \multicolumn{2}{c|}{ Province } & \multicolumn{3}{c}{ Samples } \\
\hline \multirow{5}{*}{ Districts } & Adana & I & II & III & Antalya & I & II & III & Mersin & I & II & III \\
& Tuzla & 11 & 12 & 8 & Alanya & 13 & 17 & 14 & Tarsus & 9 & 8 & 11 \\
& Karataş & 9 & 11 & 12 & Manavgat & 14 & 12 & 11 & Mezitli & 14 & 17 & 10 \\
& Yüreğir & 13 & 10 & 20 & Serik & 24 & 19 & 9 & Kocahasanlı & 19 & 9 & 11 \\
& Seyhan & 12 & 11 & 16 & Merkez & 27 & 14 & 13 & Erdemli & 19 & 10 & 11 \\
& Misis & 8 & 11 & 7 & Kemer & 7 & 6 & 1 & Silifke & 18 & 13 & 10 \\
& Ceyhan & 10 & 10 & 9 & Kumluca & 7 & 8 & 6 & Kazanlı & 10 & 8 & 14 \\
& Yumurtalık & 10 & 14 & 10 & Finike & 8 & 8 & 8 & Aydıncık & 7 & 11 & 8 \\
& & & & & Kaş & 6 & 2 & 1 & Anamur & 5 & 4 & 2 \\
\hline
\end{tabular}

I: year 2015, II: year 2016, III: year 2017

\section{PCR}

Simultaneously, there are no apparent macroscopic biotype differences between white-fly species. In autumn season, TYLCV can be monitored in every greenhouse. Predisposition for TYLCV such as low-quality greenhouse structures, openings for whiteflies, causes high infection rates (Table 3).

Considering the observations, 747(234: Adana, 255: Antalya, 258: Mersin) infected plants and 852 whiteflies (274: Antalya, 216: Mersin, 362: Adana) from different locations of the provinces were collected. Also, 91 plant samples were among them collected from open fields in Adana (Table 4).

Determination of TYLC strains by multiplex PCR: I. Multiplex primer pairs for TYLCV-Is, TYLCV-Sic and TYLCV-Mild; II. Multiplex primer pairs for TYLCV-Is, TYLCV-Sar (ES) and TYLCV-Mld. These multiplex sets differentiated the strains as expected. Same multiplex sets also used for detecting TYLCV and its strains within whiteflies. Leaf samples were studied with $25 \mu \mathrm{l}$ PCR mixture by using 96 well plates. For whitefly samples, $15 \mu 1$ PCR mixture was used due to low concentration of DNA.

The TYLCV strain specific PCR results realized that the most common infection was occurred by $100 \%$. Consequently, detected as mixed between $86 \%$ TYLCV Israel + Mild strains (Tables 4, 5, 6 and 7). Following this, 10\% TYLCV-Is + TYLCV- 
Sic, TYLCV Sic + TYLCV-Sar. $4.5 \%$ mixed infection rate was approximately $20 \%$ in Antalya, Mersin and Adana.

The sequence analysis and multiple sequence alignment were carried out using Chromas (Technelsium DNA Sequencing Software Australia) and CodonCode Corporation (Florida) software. The TYLCV strain specific PCR sequences were analyzed in National Center for Biotechnology Information (NCBI) using nucleotide BLAST. The agarose gel electrophoresis TYLCV multiplex PCR amplifications is shown in Figures $2 A, B$ and 3.

Table 4. Approximate number of collected plant and whitefly samples from greenhouses from provinces

\begin{tabular}{c|c|c|c|c|c|c|c|c}
\hline Province & $\begin{array}{c}\text { Total } \\
\text { samples }\end{array}$ & $\begin{array}{c}\text { TYLCV } \\
\text { Is }\end{array}$ & $\begin{array}{c}\text { TYLCV } \\
\text { Mld }\end{array}$ & $\begin{array}{c}\text { TYLCV } \\
\text { Sic }\end{array}$ & $\begin{array}{c}\text { TYLCV } \\
\text { Sar }\end{array}$ & $\begin{array}{c}\text { Total } \\
\text { whiteflies }\end{array}$ & B biotype & Q biotype \\
\hline Adana & 234 & 234 & 204 & 5 & 8 & 362 & 329 & 33 \\
Antalya & 255 & 255 & 215 & 57 & 27 & 274 & 257 & 17 \\
Mersin & 258 & 258 & 225 & 16 & 14 & 216 & 201 & 15 \\
Total & $\mathbf{7 4 7}$ & $\mathbf{1 0 0 \%}$ & $\mathbf{8 6 \%}$ & $\mathbf{1 0 \%}$ & $\mathbf{6 . 5 \%}$ & $\mathbf{8 5 2}$ & $\mathbf{9 2 \%}$ & $\mathbf{8 \%}$ \\
\hline
\end{tabular}

Table 5. TYLCV strains and whitefly biotypes in Adana

\begin{tabular}{|c|c|c|c|c|c|c|c|c|c|c|c|c|c|c|}
\hline \multirow[t]{2}{*}{ Adana } & \multirow[t]{2}{*}{ Total } & \multicolumn{2}{|c|}{$\begin{array}{l}\text { TYLCV } \\
\text { Is }\end{array}$} & \multicolumn{2}{|c|}{$\begin{array}{l}\text { TYLCV } \\
\text { Mild }\end{array}$} & \multicolumn{2}{|c|}{$\begin{array}{l}\text { TYLCV } \\
\text { Sic }\end{array}$} & \multicolumn{2}{|c|}{$\begin{array}{c}\text { TYLCV } \\
\text { Sa }\end{array}$} & \multirow[t]{2}{*}{ Total } & \multicolumn{2}{|c|}{$\begin{array}{l}\text { B tabaci } \\
\text { B biotype }\end{array}$} & \multicolumn{2}{|c|}{$\begin{array}{l}\text { B tabaci } \\
\text { Q biotype }\end{array}$} \\
\hline & & + & $\%$ & + & $\%$ & + & $\%$ & + & $\%$ & & + & $\%$ & + & $\%$ \\
\hline Tuzla & 41 & 41 & 100 & 32 & 78 & - & 0 & - & 0 & 51 & 46 & 91 & 5 & 9 \\
\hline Karataş & 42 & 42 & 100 & 35 & 83 & 1 & 2 & 2 & 5 & 54 & 49 & 90 & 5 & 10 \\
\hline Yüreğir & 33 & 33 & 100 & 30 & 91 & 2 & 6 & 3 & 9 & 57 & 53 & 94 & 4 & 6 \\
\hline Seyhan & 29 & 29 & 100 & 27 & 93 & 2 & 7 & 3 & 10 & 53 & 48 & 90 & 5 & 10 \\
\hline Misis & 26 & 26 & 100 & 24 & 92 & - & 0 & - & 0 & 44 & 40 & 93 & 4 & 7 \\
\hline Ceyhan & 29 & 29 & 100 & 26 & 91 & - & 0 & - & 0 & 57 & 51 & 91 & 6 & 9 \\
\hline Yumurtalık & 34 & 34 & 100 & 30 & 89 & - & 0 & - & 0 & 46 & 42 & 92 & 4 & 8 \\
\hline Total & 234 & 234 & 100 & 204 & 87 & 5 & 2 & 8 & 3.4 & 362 & 329 & 90 & 33 & 10 \\
\hline
\end{tabular}

Table 6. TYLCV strains and whitefly biotypes in Antalya

\begin{tabular}{c|c|c|c|c|c|c|c|c|c|c|c|c|c|c|c}
\hline Antalya & \multirow{2}{*}{ Total } & \multicolumn{2}{|c|}{$\begin{array}{c}\text { TYLCV } \\
\text { Is }\end{array}$} & \multicolumn{2}{c|}{$\begin{array}{c}\text { TYLCV } \\
\text { Mild }\end{array}$} & \multicolumn{2}{c|}{$\begin{array}{c}\text { TYLCV } \\
\text { Sic }\end{array}$} & \multicolumn{2}{c|}{$\begin{array}{c}\text { TYLCV } \\
\text { Sar }\end{array}$} & \multicolumn{2}{c|}{ Total } & \multicolumn{2}{c|}{$\begin{array}{c}\text { B tabaci } \\
\text { B biotype }\end{array}$} & \multicolumn{2}{|c}{$\begin{array}{c}\text { B tabaci } \\
\text { Q biotype }\end{array}$} \\
\hline & & + & $\%$ & + & $\%$ & + & $\%$ & + & $\%$ & & + & $\%$ & + & $\%$ \\
Alanya & 44 & 44 & 100 & 39 & 88 & 2 & 4.5 & 2 & 4.5 & 58 & 54 & 94 & 4 & 6 \\
Manavgat & 37 & 37 & 100 & 30 & 82 & 3 & 8 & 3 & 8 & 39 & 36 & 93 & 3 & 7 \\
Serik & 52 & 52 & 100 & 49 & 94 & 4 & 7.6 & 6 & 11.5 & 59 & 54 & 93 & 5 & 7 \\
Merkez & 54 & 54 & 100 & 41 & 76 & 11 & 20 & 6 & 11 & 35 & 34 & 98 & 1 & 2 \\
Kemer & 14 & 14 & 100 & 10 & 76 & 9 & 64 & - & 0 & 11 & 10 & 96 & 1 & 4 \\
Kumluca & 21 & 21 & 100 & 18 & 89 & 14 & 66 & 5 & 24 & 49 & 48 & 99 & 1 & 1 \\
Finike & 24 & 24 & 100 & 20 & 83 & 11 & 45 & 3 & 12.5 & 13 & 12 & 98 & 1 & 2 \\
Kaş & 9 & 9 & 100 & 8 & 90 & 3 & 33 & 2 & 22 & 10 & 9 & 96 & 1 & 4 \\
Total & $\mathbf{2 5 5}$ & $\mathbf{2 5 5}$ & $\mathbf{1 0 0}$ & $\mathbf{2 1 5}$ & $\mathbf{8 4}$ & $\mathbf{5 7}$ & $\mathbf{2 2}$ & $\mathbf{2 7}$ & $\mathbf{1 0 . 5}$ & $\mathbf{2 7 4}$ & $\mathbf{2 5 7}$ & $\mathbf{9 3 . 7}$ & $\mathbf{1 7}$ & $\mathbf{6 . 3}$ \\
\hline
\end{tabular}


Table 7. TYLCV strains and whitefly biotypes in Mersin

\begin{tabular}{|c|c|c|c|c|c|c|c|c|c|c|c|c|c|c|}
\hline \multirow[t]{2}{*}{ Mersin } & \multirow[t]{2}{*}{ Total } & \multicolumn{2}{|c|}{$\begin{array}{l}\text { TYLCV } \\
\text { Is }\end{array}$} & \multicolumn{2}{|c|}{$\begin{array}{c}\text { TYLCV } \\
\text { Mild } \\
\end{array}$} & \multicolumn{2}{|c|}{$\begin{array}{l}\text { TYLCV } \\
\text { Sic }\end{array}$} & \multicolumn{2}{|c|}{$\begin{array}{l}\text { TYLCV } \\
\text { Sar }\end{array}$} & \multirow[t]{2}{*}{ Total } & \multicolumn{2}{|c|}{$\begin{array}{c}\text { B tabaci } \\
\text { Biotype B }\end{array}$} & \multicolumn{2}{|c|}{$\begin{array}{c}\text { B tabaci } \\
\text { Biotype Q }\end{array}$} \\
\hline & & + & $\%$ & + & $\%$ & + & $\%$ & + & $\%$ & & + & $\%$ & + & $\%$ \\
\hline Tarsus & 28 & 28 & 100 & 25 & 89 & 1 & 3.5 & 1 & 3.5 & 28 & 26 & 95 & 2 & 5 \\
\hline Mezitli & 41 & 41 & 100 & 34 & 83 & - & 0 & 2 & 5 & 35 & 34 & 98 & 1 & 2 \\
\hline Kocahasanlı & 39 & 39 & 100 & 34 & 87 & 4 & 10 & 3 & 7 & 32 & 30 & 94 & 2 & 6 \\
\hline Erdemli & 40 & 40 & 100 & 36 & 90 & 5 & 12 & 4 & 10 & 31 & 28 & 91 & 3 & 9 \\
\hline Silifke & 41 & 41 & 100 & 37 & 91 & 3 & 7 & 2 & 5 & 30 & 27 & 92 & 3 & 8 \\
\hline Kazanlı & 32 & 32 & 100 & 28 & 89 & - & 0 & 2 & 6 & 26 & 25 & 99 & 1 & 1 \\
\hline Aydıncık & 26 & 26 & 100 & 22 & 88 & 3 & 11.5 & - & 0 & 24 & 22 & 93 & 2 & 7 \\
\hline Anamur & 11 & 11 & 100 & 9 & 90 & - & 0 & - & 0 & 10 & 9 & 92 & 1 & 8 \\
\hline Total & 258 & 258 & 100 & 225 & 87 & 16 & 6.2 & 14 & 5.4 & 216 & 201 & 93 & 15 & 7 \\
\hline
\end{tabular}

Positive controls (biotype B and biotype Q) for white-fly population experiments were provided from Israel. (Dr. A. Rami Horowitz Agricultural Research Organization, Gilat Research Center, Institute of Plant Protection, Department of Entomology, Israel). B biotype white-flies in Figure 4. were determined by codominant SCAR markers Bem23-F and Bem-23-R which was developed by Bel-Kadhi (2008).

The results show that $B$. tabaci biotype B $(92 \%)$ is prevalent in the majority of the surveyed sites, whereas biotype $Q$ was only found in $8 \%$. In each three provinces where surveyed, Bemisia tabaci biotype B was the most common and effective vector for TYLCV.

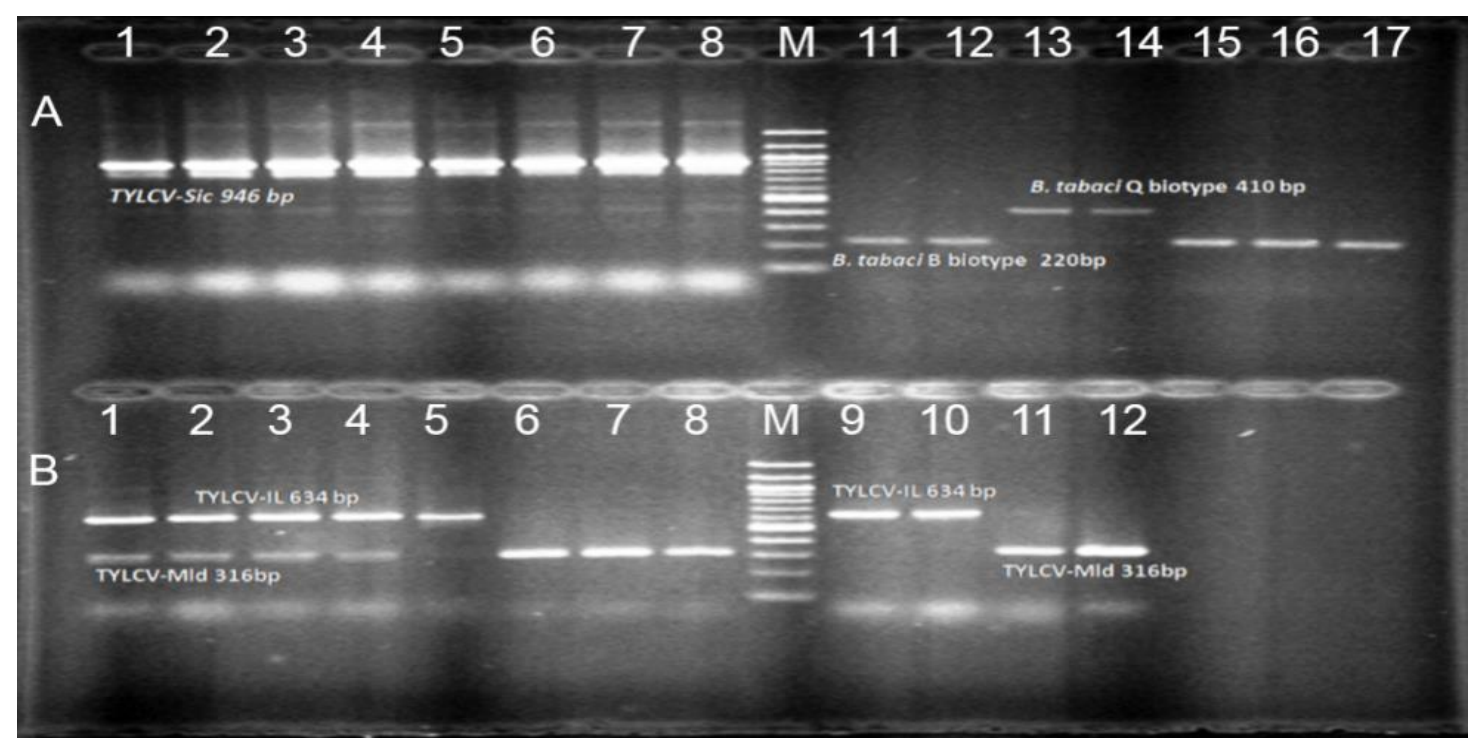

Figure 2. A Strain specific PCR results for TYLCV. Left side: 1-2 From a single whitefly TYLCV-Sic 946 bp 3-8 From infected plant TYLCV-Sic 946 bp M 100 plus bp standard DNA ladder; 11-12 B. tabaci biotype B 220 bp;13-14 B. tabaci biotype Q (410 bp); 15-17 B. tabaci biotype B by codominant SCAR markers Bem-23-F and Bem-23-R products with $220 \mathrm{bp}$. B Strain specific PCR results for TYLCV. Left side: Using Multiplex PCR set II 1-4 mix infection of TYLCV-Is (634 bp) and TYLCV-Mld (316 bp); Strain specific PCR 5-8 TYLCV-Mld single infection; M 100 plus bp standard DNA ladder; 9-10 TYLCV-Is (634 bp); 11-12 TYLCV-Mld single infection 


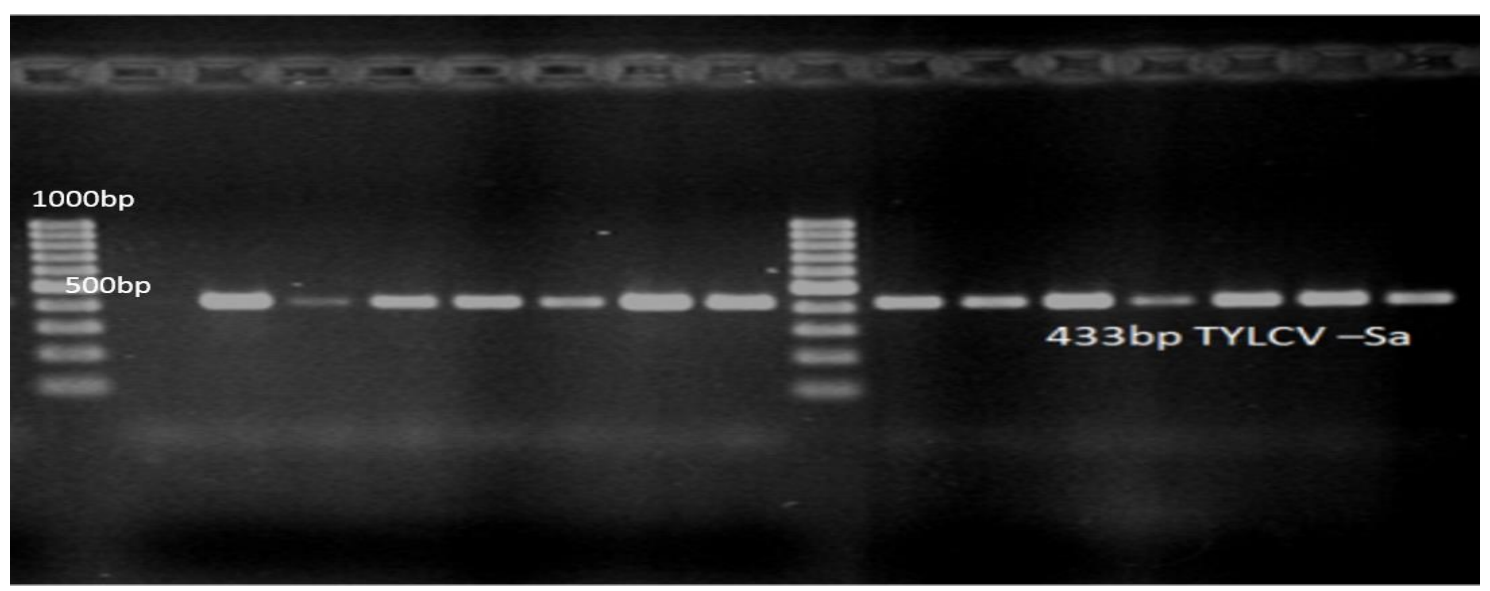

Figure 3. Strain specific PCR results for tomato yellow leaf curl Sardinia virus (TYLCSV-Sa) $433 \mathrm{bp}$

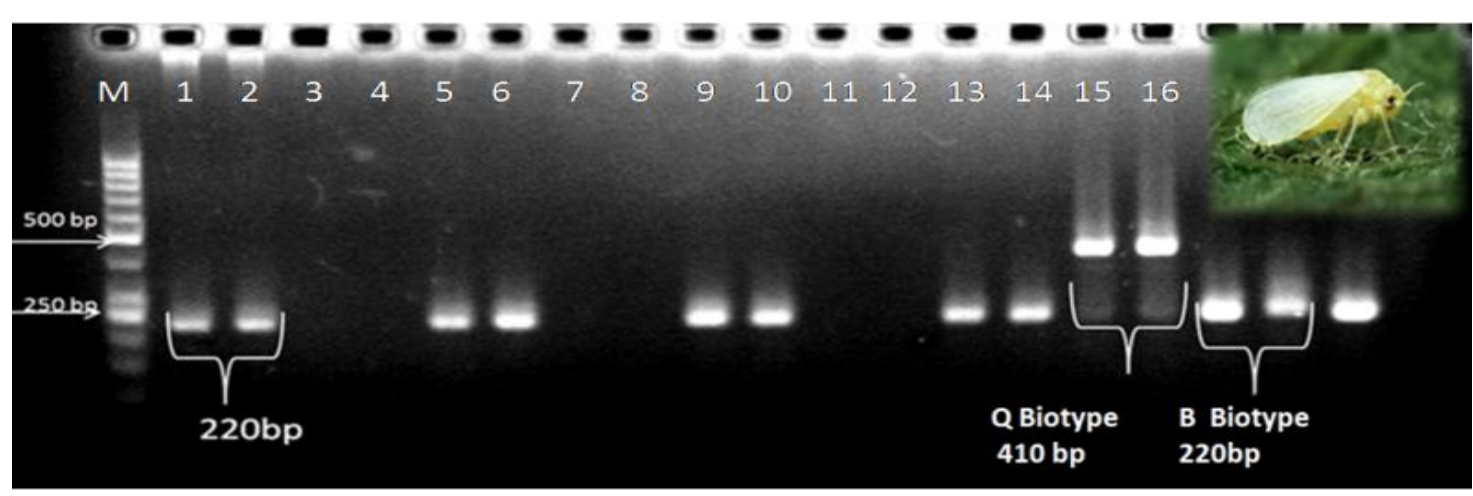

Figure 4. Gel image of one white-fly biotyping M; Thermo Scientific GeneRuler $50 \mathrm{bp}$ DNA Ladder. Line 1,2,5,6,9,10,13,14,17,18,19 B. tabaci Biotype B (220 bp), Line 15,16 Btabaci biotype $Q(410$ bp) Line 3,4 Aphis gossypii DNA samples Line 7,8; Frankliniella occidentalis DNA; 11,12; Ceratitis capitata DNA samples

\section{Phylogenetic analysis}

In sequence comparisons (NCBI Query ID lcl|29009), TYLCV Israel isolate showed 97-98\% similarity with Lebanon, Israel and Morocco isolates, Mild isolates showed 9699\% similarity with Lebanon, Spain, Italy and USA isolates. Sardinia and Sicily isolates were 94-97\% similar with Italy, Spain and Morocco isolates (|EU143755.1, AF260331.1, FJ012359.1, EU719081.1) (Fig. 5).

Haplotype analysis was evaluated at "dnasp5.exe" programmed. When isolates from three provinces compared, TYLCV-Mld isolates were belonged a haplotype, on the other hand, each TYLCV-Sic isolates had different haplotypes. TYLCV-Is and TYLCV-Sa had two haplotypes as Adana and Antalya, both Mersin and Adana isolates haplotypes were detected identical

The sequences were compared and verified in the NCBI Blast system. Verified Sequences TYLCV-Is (MH367503, MK536596) to the NCBI system; TYLCV-Mld (MK536597); TYLCV-Sar (MK536600,) and TYLCV-Sic (MK536601, MK536602) are registered as isolates. 
The phylogenetic analysis utilizes that the tree is separated into two main groups (Group I and Group II) and Group I divides to 3 subgroups. TYLCV-Mild isolate from Turkey has a unique haplotype which is clustered in Subgroup 1C despite of showing approximately $93-98 \%$ similarity with other isolates around the world. TYLCV Mild isolates from Malaga, Lebanon, and Jordan are clustered in Group 1A alongside with TYLCV-Is isolate. TYLCV-Sar and TYLCV-Sic isolates are clustered in Group 1B with other Jordan, Italy and Spain isolates which shows that these isolates are related in the terms of phylogenetic.

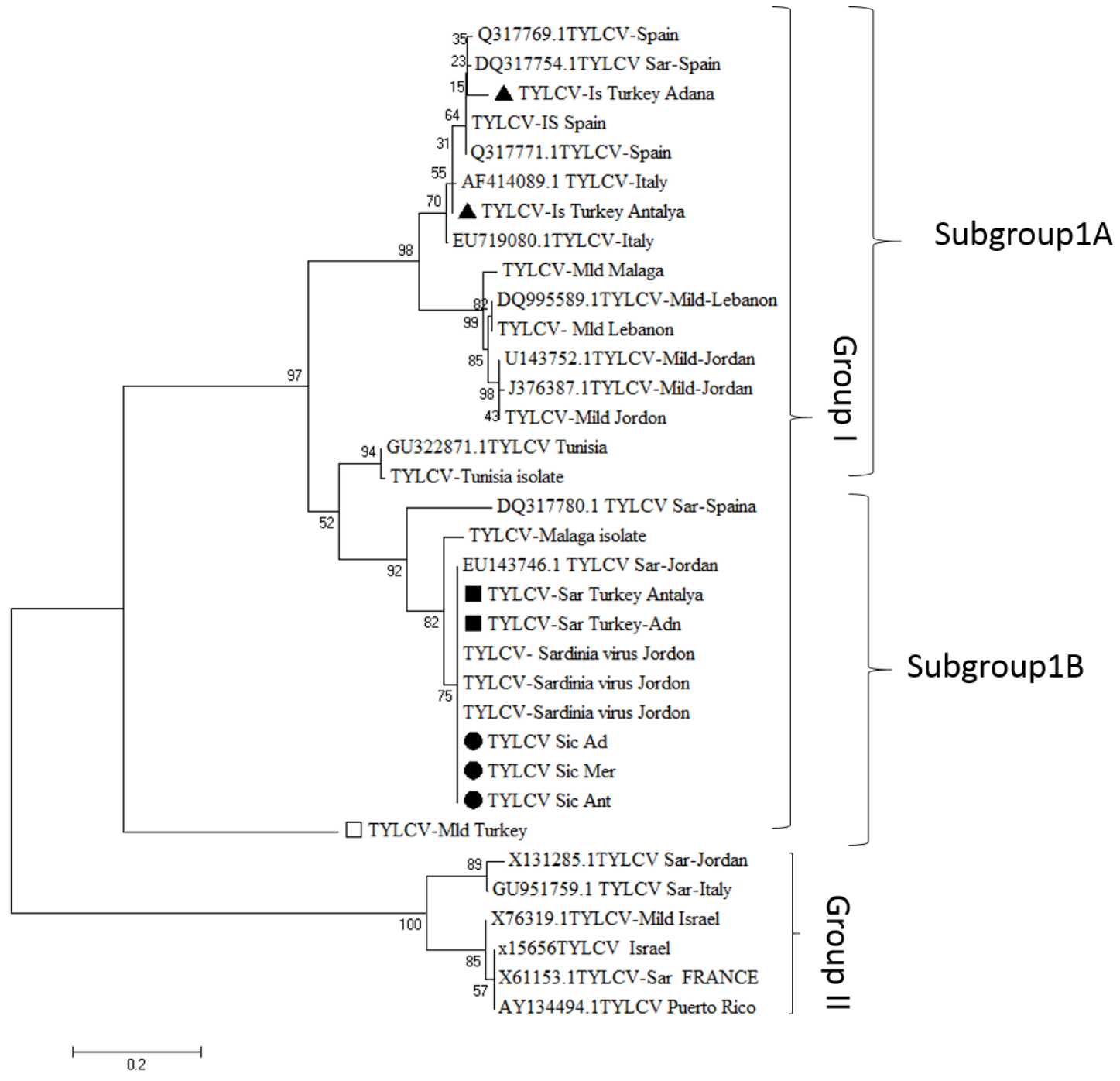

Figure 5. After haplotype analysis, phylogenetic trees were constructed with MEGA 7 programme. Related 24 isolates were selected by using BLAST analysis in NCBI database and Neighbour-joining method was used TYLCV isolates from three provinces in Turkey

\section{Discussion}

With this study, TYLCV strains and whitefly biotypes were determined which are two of the major problems of greenhouse tomato cultivation. TYLCV was observed in almost every greenhouse especially in autumn season. Temperature changes effect directly whitefly migration to greenhouses feeding behavior therefore TYLCV infection 
rate in greenhouses increases significantly as well its transmission. Although chemical management starts at threshold white-fly adult population. Nevertheless, observations showed that insecticides have not suppressed whitefly population even by rotating insecticides with different mode of action. In addition to these, insufficient knowledge of growers, presence of primitive greenhouse and growing conditions, no precautions for whiteflies such as many cavities around the greenhouses are making TYLCV infection spreading rapidly. Widespread infection causes virus to evolve more rapidly.

The most common observed strain was TYLCV-Is and TYLCV-Mld mixed infection in south coastal region of Turkey where the Mediterranean climate is dominant. On the other hand, this is the first report of TYLCV Sic. and Sar strains Mediterranean region of Turkey. Until the present study they have not been characterized and confirmed yet with reliable molecular methods such a PCR analyses at Turkey. There were TYLCVSic. strain infection found with general average $10 \%$ ratios where infections ratios were 6.2\% Mersin, 2\% Adana and 22\% Antalya provinces respectively. Furthermore, there were TYLCV-Sar infections obtained general infection rate was $6.5 \%$ where infection ratios were 3,4\% Adana, 10,5\% Antalya and 5,4\% Mersin respectively. Similar results have also determined from an individual whitefly's genomic structures had revealed TYLCV-Sic and TYLCV-Sar strains in PCR analysis.

Greenhouse studies for whiteflies showed that biotype B was the most common with aprox.92\% average in all three provinces. Other studies about the biotypes of whiteflies at vegetables in Turkey also support this result. Ulusoy et al. (2012) reported that for vegetables biotype $\mathrm{B}$ and for cotton biotype $\mathrm{Q}$ are common whitefly populations. Therefore, this supports the results about detecting 10\% biotype $\mathrm{Q}$ in Adana province (Karatas, Yuregir counties) where the production of cotton is widely done and after cotton harvest, whiteflies are rushing to higher temperature such as greenhouse tomato production areas. TYLCV transmission can be done by both B and Q biotypes however biotype B is more effective than Q biotype (Ajlan et al., 2007; Bel-Kadhi et al., 2008; Czosnek, 2008; Haider et al., 2017).

For detection, Multiplex PCR primer pairs and codominant SCAR markers was used considering the expenses, time wasting and more method steps (like RLFP) was the issue of the given methods in EPPO bulletin. This study proved that there are cheap, fast methods which have less error rates. Also there are no TYLCV Far East Asia and Africa strains in Turkey (Ohnishi et al., 2016). At least low incidence rate of Sardinia and Sicily which were South European strains (Italy, Spain, Morocco, Tunisia isolates) could be considered as positive finding of the study. Due to the fact that It is important to further exacerbate the damage caused by the existing strains. Furthermore, it is thought that there will be less chance of impact on the formation of undesired recombination between strains or isolates in the ecosystem both in and around the production area.

\section{Conclusion}

There are many ways to control TYLCV infection (Czosnek et al., 2017). Chemical control of whitefly is not the absolute solution therefore resistance to TYLCV through genetic means such as TY-1 and TY-3 genes (Zamir et al., 1994), TY-1 (Ji et al., 2007; Torre et al., 2018) or Co dominant Sequence Characterized Amplified Regions (SCAR) still are better options. Presence of many strains and multi gene controlled resistance decreased efficiency of TY1 gene. For this purpose, to overcome like breeding 
problems TY3 gene based codominant SCAR markers were developed, are supply Marker Assisted Selection for heterozygotes resistance and also homozygote susceptibility against to all Mediterranean isolates. Although there should be more studies to determine which strains involve in cultivation areas due its tendency to evolve or recombination. The strain identification has a solid importance, gives more effective directions for breeding supplied by well-characterized TYLCV strains. This study showed that there are at least four strains in Turkey and their contribution throughout Mediterranean coast. Focusing on resistant cultivars and their capacity to control the virus in Turkey as well as limiting its transmission by whiteflies could minimize damage caused by TYLCV.

The Mediterranean line has important agricultural trade areas and all kind of commercial products have been imported. This revealed contribution the natural distribution and occurrence of TYLCV in areas located. Our results pointed out the vector types with molecular techniques and sanitary conditions for TYLCV, present in tomato fields, are transmitted by white flies. The management of these vectors are so hard due to high reproductive ability, having broad range of hosts and ability to form insecticides durable species or types. In addition, the presence of vector whiteflies in the greenhouse and outside, the absence of biological and chemical control agents, takes to higher the infection. TYLCV has been spread more and more by vectors from different weeds to tomato are cultivated in greenhouse.

But nevertheless, TYLCV has a lower impact on production as it can be well controlled by molecular resistance breeding in soon.

This manuscript may also indicate sources of local TYLCV strains in tomato produced provinces. Uncontrolled distribution of $B$. tabaci types could be vectors of TYLCV strains; if whiteflies migration by air-ways or plant transportations could commence TYLCV infections at Mediterranean Countries.

The PCR technique, was standardized and successfully applied for TYLCV and $B$. tabaci biotypes, put forwarded relations between virus strain and vector bio types by Molecular assays. Therefore, Epidemiological role and feeding behaviors of Bemisia tabaci (Hemiptera: Aleyrodidae) Biotypes' for TYLCV strains on Tomato Agro Ecology in Turkey, has been become well understandable as agricultural host reservoir. Novel management strategies for disease vector complexities will be devised upon these studies to protect sanitized and resistance plants, often depends on the activation of vectors and pathogen (Razukas et al., 2007). Therefore, transmissibility of TYLCV (specially mixed infections) could be prevented.

Detailed project has planned for unknown epidemiological features of the virus vector relations (Islam et al., 2016). The determining the virus ecology and molecular origin were another outcome of results. High successful control of TYLCV spread relies upon easy discovery of these infections in stock planting material. All positive samples which were detected in this study have been eradicated.

This report is unique signature step for initiating researches on impact of whitefly vectors to the agro ecology. It is important because different virus isolates or their strains are caused disease in different host species during whitefly migration. It is possible that new isolates can result virus diseases in host plants even mixed or different isolates in whiteflies will cause possible recombination. This is not possible to estimate the adverse effects and epidemiology of the recombinants in the agricultural ecology and in the natural ecology without observing or living. 
Acknowledgments. Thanks to: Republic of Turkey Ministry of Agriculture and Forestry General Directorate of Agricultural Research and Polices Project Number TAGEM-BS-10/10-01 /02-08

Conflict of interests. The authors declare that they have no conflict of interests.

Ethical approval. This article does not contain any studies with human participants or animals performed by any of the authors.

\section{REFERENCES}

[1] Abak K., Y1lmaz M. A., Kesici S. (1991): Problème de TYLCV en Turquie et moyen sutilisés pour diminuer son effet. - Proceeding of Seminar on Resistance to TYLCV, Avignon 1991, pp. 28-30.

[2] Abhary, M. K., Anfoka, G. H., Nakhla, M. K., Maxwell, D. P. (2006): Posttranscriptional gene silencing in controlling viruses of the tomato yellow leaf curl virus complex. - Archives of Virology 151: 2349-2363.

[3] Accotto, G. P., Navas-Castillo, J., Noris, E., Moriones, E., Louro, D. (2000): Typing of tomato yellow leaf curl viruses in Europe. - Eur. J. Plant Pathol. 106: 179-186.

[4] Ajlan, A., MGhanem, G. A. M., Abdulsalam, K. S. (2007): Tomato yellow leaf curl virus (TYLCV) in Saudi Arabia: identification, partial characterization and virus-vector relationship. - Arab J. Biotech. 10(1): 179-192.

[5] Anfoka, G. H., Abhary, M., Nakhla, M. K. (2005): Molecular identification of species of the Tomato yellow leaf curl virus complex in Jordan. - J. Plant Pathol. 87: 61-66.

[6] Anfoka, G., Abhary M., Haj Ahmad, A. F., Hussein, A., Rezk, F., Akad, Y., AbouJawdah, M. et al. (2008): Survey of tomato yellow leaf curl disease-associated viruses in the eastern Mediterranean basin. - Journal of Plant Pathology 90(2): 311-320.

[7] Avidov, H. Z. (1944): Tobacco Whitefly in Israel. - Hassadeh, Tel Aviv, pp. 1-33 (in Hebrew).

[8] Bayhan, E., Ulusoy, M. R., Brown, J. K. (2006): Host species, distribution, and natural enemies of Bemisia tabaci "B biotype" (Homoptera: Aleyrodidae) in Turkey. - J. Pestic. Sci. 79: 233-240.

[9] Bel-Kadhi, M. S., Onillon, J. C., Cenis, J. L. (2008): Molecular characterization of Bemisia tabaci biotypes in Southern Tunisia. - Tunisian Journal of Plant Protection 3: 7985.

[10] Boulton, M. I. (2003): Geminiviruses: major threats to world agriculture. - Ann. Appl. Biol. 142: 143.

[11] Brown, J. K., Czosnek, H. (2002): Whitefly Transmitted Viruses. - Academic Press, New York, pp. 65-100.

[12] Czosnek, H. (2008): Tomato Yellow Leaf Curl Virus. - In: Mahy, B. W. J., Van Regenmortel, M. H. V. (eds.) Encyclopedia of Virology. Elsevier, Oxford, pp. 138-145.

[13] Czosnek, H., Laterrot, H. (1997): A worldwide survey of tomato yellow leaf curl viruses. Arch. Bemisia tabaci. - J. Gen. Virol. 72: 2607-2614.

[14] Czosnek, H., Shalev, A. H., Sobol, H., Gorovits, R., Ghanim, M. (2017): The incredible journey of Begomo viruses in their whitefly vector. - Viruses 9: 273. DOI: 10.3390/v9100273.

[15] Fauquet, C. M., Briddon, R. W., Brown, J. K., Moriones, E., Stanley, J., Zerbini, M., Zhou, X. (2008): Geminivirus strain demarcation and nomenclature. - Arch Virol 153: 783-821.

[16] Gronenborn, B. (2007): The Tomato Yellow Leaf Curl Virus Genome and Function of Its Proteins. - In: Czosnek, H. (ed.) Tomato Yellow Leaf Curl Virus Disease: Management, Molecular Biology, Breeding for Resistance. Springer, Dordrecht, pp. 67-84.

[17] Haider, S., Khan, M. A., Jahanzaib, M. (2017): Characterization of epidemiologicalfactorsforthewhitefly (Bemisiatabaci Genn.) population and tomato leaf 
curl virus disease (TLCVD) incidence on tomato genotypes in Faisalabad. - Pakistan Journal of Entomology and Zoology Studies 5(4): 747-752.

[18] Islam, W., Zhang, J., Adnan, M., Noman, A., Zaynab, M., Wu, Z. (2016): Plant virus ecology: a glimpse of recent accomplishments. - Applied Ecology and Environmental Research 15(1): 691-705.

[19] Isler, N., Ozgur A. F. (1992): The effect of planting time and row spacing on population development of whitefly (Bemisia tabaci) and plant phenology and yield. - Turk. Entomol. Dergisi 16: 87-98.

[20] Ji, Y., Schuster, D. J., Scott, J. W. (2007): Ty-3, a begomovirus resistance locus near the Tomato yellow leaf curl virus resistance locus Ty-1 on chromosome 6 of tomato. - Mol Breeding 20: 271-284.

[21] Jones, D. R. (2003): Plant viruses transmitted by whiteflies. - Eur. J. Plant Pathol. 109: 195-219.

[22] Karut, K., Malik, A. A. Y., Kazak, C., Kamberoğlu, M. A., Ulusoy, M. R. (2012): Determination of biotypes of bemisia tabaci (Gennadius 1889) (Hemiptera: Aleyrodidae) on different host plant in Adana (Balcali) by using two different molecular methods. Turkiye Entomoloji Dergisi - Turkish Journal of Entomology 36: 93-100.

[23] Karut, K., Kaydan, M. B., Tok, B., Döker, İ., Kazak, C. (2015): A new record for (Gennadius) (Hemiptera species complex of Turkey. - Journal of Applied Entomology 139: 158-160.

[24] Konjevic, A., Milovac, Z., Kontsedalov, S., Kanakala, S., Ghanim, M. (2018): First interception of Bemisiatabaci Mediterranean (Q biotype) in Serbia. - J. Appl. Entomol. 142: 627-631.

[25] Li, J., Ding, T. B., Chi, H., Chu, D. (2017): Effects of tomato chlorosis virus on the performance of its key vector, Bemisiatabaci, in China. - J. Appl. Entomol. 142(3): 296304.

[26] Moriones, E., Navas-Castillo, J. (2000): Tomato yellow leaf curl virus, an emerging virus complex causing epidemics worldwide. - Virus Res. 71: 123-134.

[27] Navas-Castillo, J., Fiallo-Olivé, E., Sánchez-Campos, S. (2011): Emerging virus diseases transmitted by whiteflies. - Ann Rev Phytopathol. 49: 219-248.

[28] Ohnishi, J., Yamaguchi, H., Saito, A. (2016): Analysis of the mild strain of tomato yellow leaf curl virus, which overcomes Ty-2 gene-mediated resistance in tomato line H24. Arch. Virol. 161(8): 2207-17. DOI: 10.1007/s00705-016-2898-4.

[29] Papayiannis, L. C., Katis, N. I., Idris, A. M., Brown, J. K. (2011): Identification of weed hosts of Tomato yellow leaf curl virus in Cyprus. - Plant Dis. 95: 120-125.

[30] Razukas, A., Jundulas, J., Asakaviciute, R. (2007): Potato cultivars susceptibility to potato late blight (Phytopthtora infestans). - Applied Ecology and Environmental Research 6(1): 95-106.

[31] Sambrook, J., Fritschi, E. F., Maniatis, T. (1989): Molecular Cloning: A Laboratory Manual. - Cold Spring Harbor Laboratory Press, New York.

[32] Satar, G., Ulusoy, M. R. (2016): Biotype detection of Bemisia tabaci (Gennadius) (Hemiptera: Aleyrodidae) populations collected from Mediterranean Region Türk. Entomol. bült. 6(3): 205-212.

[33] Torre, C., Donaire, L., Gómez-Aix, C., Juárez, M., Peterschmitt, M., Urbino, C., Hernando, Y., Agüero, J., Aranda, M. A. (2018): Characterization of begomoviruses sampled during severe epidemics in tomato cultivars carrying the $T y-1$ Gene. - Int. J. Mol. Sci. 19: 2614.

[34] Ulusoy M. R., Karut K., Çalişkan A. F. (2012): Faunistic studies on Aleyrodidae species of Aegen Region. - Türkiye Entomoloji Bülteni 2: 251-267.

[35] Yilmaz, M. A. (1978): Domateslerde Domates Sarı Yaprak Kıvırcıklık Virüsü. - Doğa 2: 248-250. 


$$
\text { - } 9144 \text { - }
$$

[36] Zamir, D., Ekstein Michelson, I., Zakay, Y., Navot, N., Zeidan, M., Sarfatti, M., Eshed, Y., Harel, E., Pleban, T., van Oss, H. (1994): Mapping and introgression of a tomato yellow leaf curl virus tolerance gene, Ty-1. - Theor Appl Genet 88:141-146.

[37] Zeidan, M., Czosnek, H. (1991): Acquisition of tomato yellow leaf curl virus by the whitefly Bemisia tabaci. - Journal of General Virology 72: 2607-2614. 